\title{
SISTEM INFORMASI PENDAFTARAN PENDAMPINGAN LEGALISASI PRODUK UMKM PROVINSI BANTEN BERBASIS WEB MENGGUNAKAN METODE SDLC PADA PKPH UNMA BANTEN
}

\author{
Agung Sugiarto ${ }^{1}$, Susilawati ${ }^{2}$, Ropi Hidayat $^{3}$ \\ Universitas Mathla'ul Anwar Banten ${ }^{1,2,3}$ \\ Correspondence Author: agung.sugiarto@unmabanten.ac.id
}

\begin{abstract}
The UMKM Legalization Assistance Registrasi Information System is a program specifically designed to make it easier for UMKM to register and assist the legalization of UMKM products. PKPH (Center for Halal Product Studies) is an institution that assists UMKM in product legalization This system is a system that explains product legalization registration for assistance to MSMEs. With this system, it is hoped that the management of UMKM can easily find out information on UMKM that will legalize their products. This information system is designed using Flow Of System (FOS), Contect Diagrams, Data Flow Diagrams (DFD), Entity Relationship Diagrams (ERD), and uses the Tools Tets Editor Visual Studio Code with programming language and PHP Fremwork Laravel, HTML Language, CSS Using Bootstrap and Database using MySql. The results are in the form of Main Page, Registration, Scheduling, News and Admin menus. The application of this application is carried out by registering a domain that can be accessed anywhere with an internet connection By implementing this Registrasi System using the SDLC (System Development Live Cycle) method, it is hoped that it will be able to provide solutions for MSME administrators who carry out product legality.
\end{abstract}

Keywords: PKPH UNMA Banten, System, Register, UMKM, Web

Abstrak: Sistem Informasi Pendaftaran Pendampingan Legalisasi Produk UMKM merupakan program yang dirancang khusus untuk memudahkan pihak UMKM dalam melakukan registarsi dan pendampingan legalisasi produk UMKM. PKPH (Pusat Kajian Produk Halal) salah satu lembaga yang mendampingi UMKM dalam legalisasi Produk Sistem ini merupakan sebuah sistem yang menjelaskan tentang registrasi legalisasi produk untuk pendampingan pada UMKM. Dengan sistem ini, diharapkan para pengurus UMKM bisa dengan mudah mengetahui informasi UMKM yang akan Legalisasi produk nya. Sistem Informasi ini dirancang dengan menggunakan Flow Of System (FOS), Contect Diagram, Data Flow Diagram (DFD), Entity Relationship Diagram (ERD), dan menggunakan Tools Tets Editor Visual Studio Code dengan bahasa pemerogramand PHP Fremwork Laravel, Bahasa HTML, CSS Menggunakan Bootstrap dan Database menggunakan MySql. Hasilnya berupa menu Halaman Utama, Registrasi, Penjadwalan, Berita dan Admin. Penerapan aplikasi ini dilakukan dengan mendaftarkan domain yang dapat diakses dimanapun dengan koneksi internet Dengan Implementasi Sistem Pendaftaran ini menggunakan metode SDLC (System Development Live Cycle) diharapkan mampu memberikan solusi mengenai pengurus UMKM yang melakukan legalitas produk.

Kata Kunci: PKPH UNMA Banten, Sistem, Pendaftaran, UMKM, Web 


\section{PENDAHULUAN}

Perkembangan ilmu pengetahuan dan teknologi tidak terlepas dari perkembangan kebutuhan manusia. Berbagai kebutuhan mendorong daya pikir manusia untuk mengembangkan teknologi sehingga dapat memberi kemudahan-kemudahan dalam setiap kehidupan, salah satu bidang ilmu pengetahuan dan teknologi yang sedang berkembang dengan pesat adalah sistem teknologi informasi Ketentuan umum UU Nomor 33 Tahun 2014, tentang jaminan produk halal untuk menjamin ketersediaan produk halal, ditetapkan bahan produk yang dinyatakan halal, baik bahan yang berasal dari bahan baku hewan, tumbuhan, mikroba, maupun bahan yang dihasilkan melalui proses kimiawai, proses biologi, atau proses rekayasa genetik. Di samping itu, ditentukan pula PPH yang merupakan rangkaian kegiatan untuk menjamin kehalalan Produk yang mencakup penyediaan bahan, pengolahan, penyimpanan, pengemasan, pendistribusian, penjualan, dan penyajian Produk Pusat Kajian Produk Halal (PKPH) UNMA Banten merupakan sebuah lembaga yang Memfasilitasi pihak UMKM dan Industri dalam pengurusan sertifikat halal, Memberikan layanan pendampingan dan konsultasi halal pada UMKM, Industri, dan masyarakat umum, Sosialisasi ke masyarakat umum mengenai pentingnya "halal is lifestyle", Membuat komunitas melalui media sosial yang berisi informasi terkait halal, Melakukan riset halal serta publikasi di jurnal, media, Jasa laboratorium untuk mendukung analisis mengenai kehalalan suatu produk, Mengembangkan sistem pengembangan profesi yang terkait jaminan produk halal dan branding halal produk dan lainnya. Pusat Kajian Produk Halal (PKPH) memberikan layanan pendampingan dan konsultansi halal pada UMKM untuk memberikan pelayanan kehususnya pada UMKM di Pandeglang, produk dalam kategori makanan, kosmetik, obat-obatan untuk memudahakan UMKM memberikan label halal pada produk yang diolah oleh UMKM. Memperoleh sertifikat halal diawali dengan pengajuan permohonan sertifikat halal oleh Pelaku Usaha kepada BPJPH. Slanjutnya, BPJPH melakukan pemeriksaan kelengkapan dokumen. Pemeriksaan dan/atau pengujian kehalalan Produk dilakukan oleh LPH. LPH tersebut harus memperoleh akreditasi dari BPJHP menerbitkan Sertifikat Halal berdasarkan keputusan penetapan Halal Produk yang ditandatangani oleh MUI. BPJPH menerbitkan Sertifikat Halal berdasarkan keputusan Penetapan Halal Produk dari MUI tersebut. Hal inilah yang melandaskan semua produk yang sudah dinyatakan halal oleh melalui fatwa MUI (Majelis Ulama Indonesia) wajib mencantumkan logo halalnya.

Sistem dapat didefinisikan sebagai kumpulan komponen-komponen yang bekerja sama untuk tujuan bersama. Misalnya bidang organisasi keuangan, operasi dan pemasaran memiliki tujuan yang sama untuk mencapai tujuan perusahaan secara keseluruhan. Hal ini dapat dilihat bahwa dalam sistem, data digunakan sebagai input untuk diproses yang menghasilkan informasi sebagai output.[1]

Informasi adalah data yang telah dikelola dan di proses untuk memberikan arti dan memperbaiki proses pengambilan keputusan.[2]

Metode SDLC (Systems Development Life Cycle, Siklus Hidup Pengembangan Sistem) atau Systems Life Cycle (Siklus Hidup Sistem), dalam rekayasa sistem dan rekayasa perangkat lunak, adalah proses pembuatan dan pengubahan sistem serta model dan 
metodologi yang digunakan untuk mengembangkan sistem-sistem tersebut. Konsep ini umumnya merujuk pada sistem komputer atau informasi. SDLC juga merupakan pola yang diambil untuk mengembangkan sistem perangkat lunak, yang terdiri dari tahap-tahap: rencana (planning), analisis (analysis), desain (design), implementasi (implementation), uji coba (testing) dan pengelolaan (maintenance). Dalam rekayasa perangkat lunak, konsep SDLC mendasari berbagai jenis metodologi pengembangan perangkat lunak. Metodologi-metodologi ini membentuk suatu kerangka kerja untuk perencanaan dan pengendalian pembuatan sistem informasi, yaitu proses pengembangan perangkat lunak. Terdapat 3 jenis metode siklus hidup sistem yang paling banyak digunakan, yakni: siklus hidup sistem tradisional (traditional system life cycle), siklus hidup menggunakan prototyping (life cycle using prototyping), dan siklus hidup sistem orientasi objek (object-oriented system life cycle). [2]

Php merupakan singkatan dari "Hypertext Preprocessor" adalah sebuah bahasa scripting yang terpasang dari HTML. Sebagian besar sintax mirip dengan bahasa C, java dan Perl,ditambah beberapa fungsi PHP yang sfesifik .tujuan bahasa ini adalah untuk memungkinkan perancang web menulis halaman web dinamik dengan cepat. PHP dikatakan sebagai sebuah server side embedded script language artinya sintaks-sintaks dan perintah yang kita berikan akan sepenuhnya dijalankan oleh server tetapi disertakan padahalaman HTML. Aplikasi aplikasi yang dibangun oleh PHP pada umumnya akan memberikan hasil pada web browser, tetapi prosesnya secara keseluruhan dijalankan di server.

MYSQL adalah perangkat lunak sistem manajemen system atau DBMS yang multithread,multi-user,MYSQL tersedia sebagai perangkat lunak gratis dibawah lisensi (GNU) General public Licence (GPL)

Visual Studio Code adalah aplikasi editor untuk code dan text yang dapat berjalan diberbagai operating system. Yang digunakan untuk membangun sebuah aplikasi website dan aplikasi lainnya.

Pusat Kajian Produk Halal (PKPH) UNMA Banten adalah sebuah lembaga pusat kajian produk halal yang berlokasi di Gedung G , Universitas Mathla'ul Anwar Banten Jalan Raya Labuan Km 23 Saketi Pandeglang Banten dan sudah berdiri sejak 23 April 2017.

PKPH UNMA Banten yang di ketuai oleh Hadi Susilo, S.Si., M.Si. (Fakultas Sains dan Farmasi), memiliki visi menjadi pusat kajian halal terkemuka yang mendukung pengembangan produk halal di Indonesia dan global, dengan salah satu misinya adalah membantu UMKM dan perusahaan dalam mengurus sertifikat halal. [9]

\section{METODE}

Metode Pengumpulan Data

Teknik pengumpulan data yang dilakukan menggunakan observasi dan wawancara. Observasi adalah mengamati. Observasi dilakukan dengan menggunakan indra penglihatan dan indra pendukung lainnya, seperti pendengaran, penciuman dan lain-lain untuk mencermati secara langsung fenomena atau objek yang sedang kita teliti. 
Wawancara adalah metode pengambilan data yang dilakukan dengan cara menanyakan kepada responden secara langsung dan bertatap muka tentang beberapa hal yang diperlukan dari suatu fokus penelitian. (A. Ghani dkk, 2016).

Metode pengembangan sistem yang digunakan dalam pengembangan pada sistem ini adalah metode SDLC (Systems Development Life Cycle), dengan tahapan sebagai berikut: rencana (planning), analisis (analysis), desain (design), implementasi (implementation), uji coba (testing) dan pengelolaan (maintenance).

\section{HASIL DAN PEMBAHASAN}

\section{A. Implementasi dan Uji Coba}

1. Flow Of System

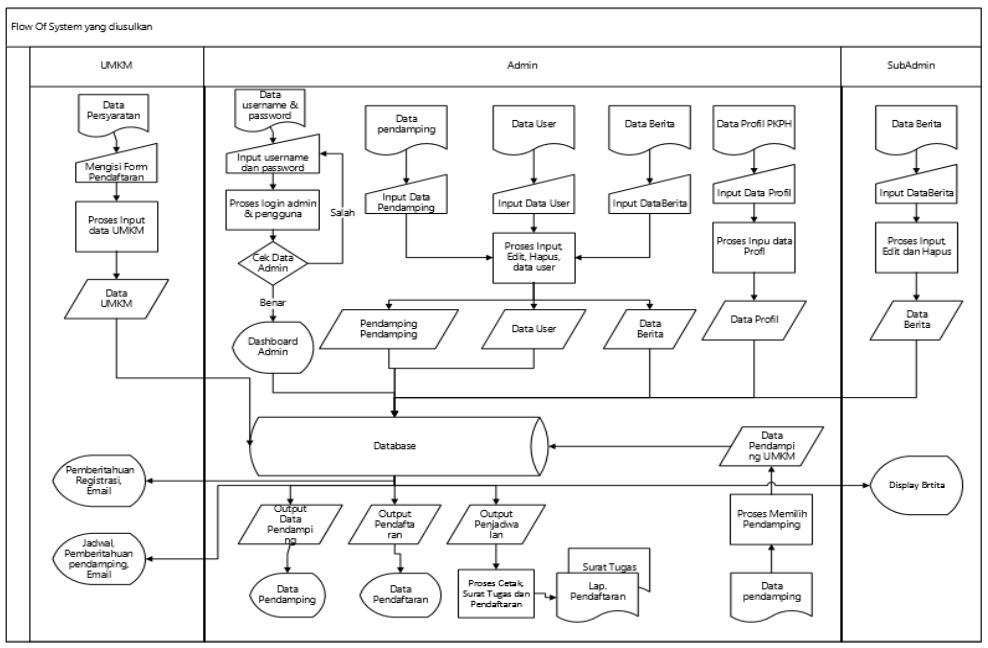

Gambar 1. Flow Of System

2. Diagram Konteks

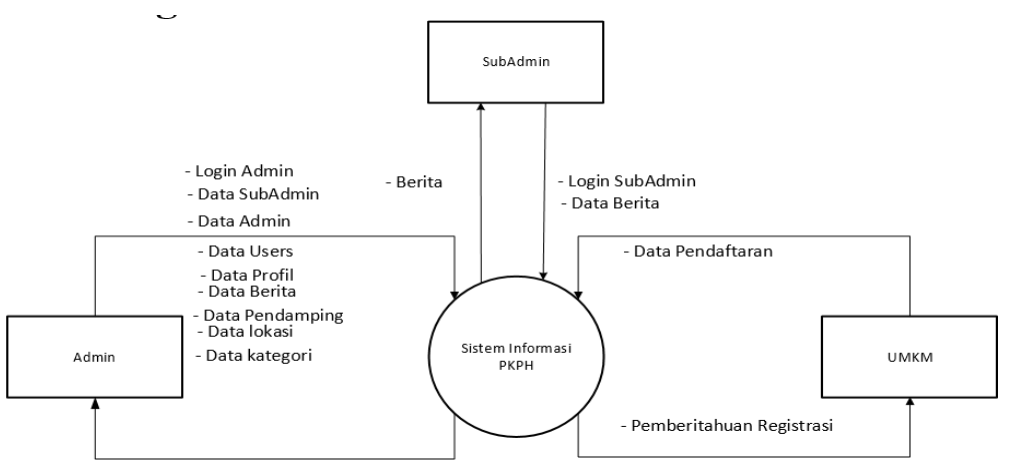

Gambar 2. Diagram Konteks

\section{B. Kebutuhan Software, Hardware, dan Brainware}

Untuk menunjang pelaksanaan pengaplikasian pembuatan program yang dibutuhkan beberapa faktor pendukung diantaranya. 


\section{Kebutuhan Software untuk membuat program}

- Sistem operasi windows 10

- XAMMP v.3.2.3

- PHP Versi 7.1.28

- $\quad$ Google Chrome Versi 83.0.4

- Visual Studio Code Versi 1.47.2

2. Kebutuhan Hardware untuk membuat Program

- Processor AMD A8

- Hard disk Kapasitas 500 GB

- Ram 4 GB

- Keyboard dan Mouse

\section{Kebutuhan Brainware}

Perangkat keras dan perangkat lunak tidak akan berguna apabila tidak ada brainware (pengguna) yang mengoprasikannya. Adapun brainware (pengguna) yang terlibat dalam sistem adalah konsument sebagai member, direktur dan bagian admin sistem.

\section{Implementasi Sistem}

1. Tampilan Menu Login

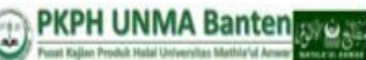

PKPH UNMA Bantengre

Gambar 3. Tampilan Menu Login

2. Tampilan Input Pendampingan

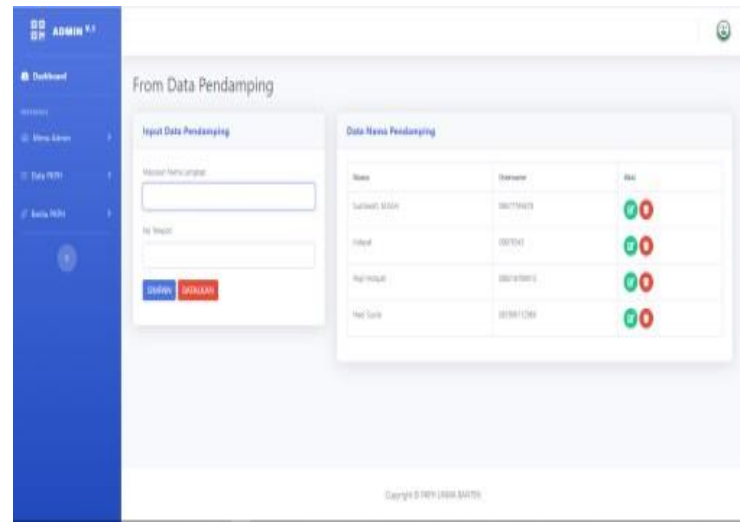

Gambar 4. Tampilan Input Pendampingan 


\section{Pengujian Sistem}

Dilakukan untuk memriksa kinerja anter komponen sistem yang di implementasikan. Adapun rencana pengujian sistem yang akan di uji dengan tenik pengujian Black Box, Berikut rincian pengjian tabel di bawah ini.

Tabel I. Pengujian Sistem

\begin{tabular}{|c|l|l|l|}
\hline No & Kelas Ứi & Butir Uji & $\begin{array}{c}\text { Jenis } \\
\text { Pengujian }\end{array}$ \\
\hline 1 & Login & Blackbox \\
\hline 2 & $\begin{array}{l}\text { Pengolahan } \\
\text { data }\end{array}$ & $\begin{array}{l}\text { Pengolahan } \\
\text { berita }\end{array}$ & Blackbox \\
\hline 3 & $\begin{array}{l}\text { Pengolahan } \\
\text { data }\end{array}$ & $\begin{array}{l}\text { Pengolahan } \\
\text { data registrasi }\end{array}$ & Blackbox \\
\hline 4 & $\begin{array}{l}\text { Pengolahan } \\
\text { data }\end{array}$ & $\begin{array}{l}\text { Pengolahan } \\
\text { data } \\
\text { pendamping }\end{array}$ & Blackbox \\
\hline 5 & $\begin{array}{l}\text { Pengolahan } \\
\text { data }\end{array}$ & $\begin{array}{l}\text { Pengolahan } \\
\text { penjadwalan } \\
\text { Pendampingan }\end{array}$ & Blackbox \\
\hline
\end{tabular}

\section{KESIMPULAN}

Berdasarkan hasil penelitian, perancangan dan pembahasan yang telah diuraikan pada bab-bab sebelumnya, dengan mengacu pada beberapa teori dan hasil penelitian sebelumnya, dapat ditarik kesimpulan sebagai berikut :

1. Sistem Informasi pendaftaran pada UMKM ini dibuat dengan berbasis website, sehingga dapat membantu mempermudah pendampingan.

2. Sistem ini memiliki pemberitahuan registrasi melalui email dan konfirmasi pelaksanan.

Adapun saran-saran dari penulis untuk penggunaan website pendampingan ini dapat diperhatikan sebagai berikut :

1. Dalam menggunakan website pendampingan ini, agar dapat diakses dengan cepat disarankan menggunakan koneksi internet yang stabil.

2. Dalam pengembangan sistem pendampingan ini kedepannya di harapkan sudah dapat menggunakan android untuk mengikuti kemajuan zaman.

3. Bagi admin dalam pemeliharaan database agar selalu memperhatikan ruang penyimpanan, penggunaan ruang penyimpanan sangat disarankan hanya untuk data yang valid.

\section{DAFTAR PUSTAKA}

[1] Abd. Rahman A. Ghani. (2016). Metodelogi Penelitian Tindakan Sekolah.Jakarta: Rajawali Pers.

[2] Canggih Ajika Pamungkas. (2017). Pengantar dan Implementasi Basis Data. Yogyakarta: Deepublish. 
[3] Enterprise, Jubilee. (2014). MySQL untuk Pemula, Jakarta: PT Elex Media Komputindo.

[4] Indrajani.(2018).Database design All in oneTheory, and case study.Jakarta:Kompas Gramedia.

[5] Indrajani.(2015). Database Design Case Study All in one.Jakarta:Kompas Gramedia.

[6] Indrajani.(2011). Perancangan Basisdata dalam All in 1.Jakarta:Gramedia.

[7] Maulani, T.R., dkk.(2020). Deteksi Cemaran DNA Babi Dengan RT-PCR Pada Sosis Tanpa Logo Halal di Kabupaten Pandeglang. Gorontalo Agriculture Technology Journal Volume 3, No 2, Oktober 2020.

[8] Meilan Anastasia Maharani. (2018). Analisis dan prancangan sistem informasi dengan Codeigniter dan Laravel, Yogyakarta: CV. Lokomedia.

[9] Maniah. \& Dini Hamidin. (2017). Analisis dan Perancangan Sistem Informasi Pembahasan Secara Praktis Dengan Contoh Kasus, Yogayakarta: Deepublish.

[10] Sugiarto, Agung. (2018). Sistem Informasi Pelayanan Administrasi pada Desa Ramaya Kecamatan Menes dengan Metode Waterfall. Seminar Nasional Rekayasa Teknologi Informasi. SNARTISI, Vol. I (November), p.99-103.

[11] PKPH UNMA Banten, (2017). Pusat Kajian Produk Halal Universitas Mathla'ul Anwar Banten, Diakses pada 21 Mei 2021, dari www.halalunmabanten.id.

[12] Wibowo, G.I. dkk. (2014). Perancangan Aplikasi Gudang Pada PT. Pakan Ternak Sejati. E-Journal Teknik Elektro dan Komputer.

[13] Roni Abdulloh. (2018). 7 in 1 Pemrograman Web untuk Pemula. Jakarta: Kompas Gramedia

[14] Rizkypermanap (2017). Pengertian dan tahapantahapan metode SDLC,

[15] Yan Watequlis Syifudin, dkk. (2018). Dasar Pemrograman, Malang: Polimena Press.

[16] Yuliaseptiani, (2017). Definisi sistem karakteristik sistem dan klasifikasi sistem. 